THE PASSION PROJECTS 



\section{The Passion Projects}

MODERNIST WOMEN, INTIMATE ARCHIVES, UNFINISHED LIVES

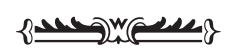

Melanie Micir 
Copyright (C) 2019 by Princeton University Press

Published by Princeton University Press

41 William Street, Princeton, New Jersey 08540

6 Oxford Street, Woodstock, Oxfordshire OX20 1TR

press.princeton.edu

All Rights Reserved

Library of Congress Control Number 2019931723

ISBN 978-o-691-19311-3

British Library Cataloging-in-Publication Data is available

Editorial: Anne Savarese and Jenny Tan

Production Editorial: Jill Harris

Jacket Design: Pamela Schnitter

Production: Merli Guerra

Publicity: Alyssa Sanford and Keira Andrews

Jacket images: (Silhouette) Lucie Delarue-Mardrus.

(Inside silhouette) Sylvia Townsend Warner

This book has been composed in Miller

Printed on acid-free paper. $\infty$

Printed in the United States of America

109876554321 
For Anna and Maeve Anna 

I felt like I was managing a huge building site, from which I was going to excavate a miniature model of modernity, reduced to its simplest, most complex form: a woman telling her story through that of another woman. -NATHALIE LÉGER, SUITE FOR BARBARA LODEN 
